\title{
Fair Freedom of Contract in Oil and Gas Construction Contract
}

\author{
Reza Pahlevi \\ \{Pahlevisk.reza@gmail.com\} \\ Student of Doctor of Law Program, University of Pelita Harapan
}

\begin{abstract}
Indonesia adheres to the notion of a welfare state as mandated in Article 33 of the 1945 Constitution. Management of oil and gas by KKKS is subject to PTK 007 Rev.04 and refers to Article 1320 of the Civil Code. The definition of a construction work contract is regulated in Law Number 2 of 2017 concerning Construction Services which is analyzed using UNIDROIT. This study uses a normative method. It can be concluded that the freedom of contract arrangement has been adequate. However, its implementation still raises problems related to aspects of justice and balance. The description of the principle of freedom of contract in operational arrangements contains inconsistencies that create legal uncertainty and corner the position of the contractor. For this reason, the guidelines for oil and gas construction contracts need to be improved by adding regulations that ensure justice, certainty and efficiency.
\end{abstract}

Keywords: Freedom of Contract, Fairness, Oil and Gas Contract

\section{Introduction}

The Unitary State of the Republic of Indonesia (NKRI) adheres to the concept of a welfare state. This is reflected in Article 33 of the 1945 Constitution [1] Then according to Kranenburg, which is explained in the theory of welfarestate, welfarestate not only maintains legal order, but also actively strives for the welfare of its citizens. In addition, efforts to achieve state goals need to be based on equitable and balanced justice. [2]

Based on Government Regulation Number 35 of 2004 concerning Upstream Oil and Gas Business Activities which was later amended by Government Regulation Number 35 of 2005 concerning Upstream Oil and Gas Business activities, upstream business activities include exploration and exploitation activities. [3] In this case, it will focus on the upstream sector whose supervision is carried out by the Special Task Force for Upstream Oil and Gas Business Activities (SKK Migas).

The Government of the Republic of Indonesia in its efforts to meet oil and gas needs has established a strategic plan for oil and gas, one of which is to accelerate the development of oil and gas infrastructure. [4] Accelerating oil and gas infrastructure development can be carried out with several types of construction service models which are divided into traditional or conventional contracts, turn key contracts, design and build contracts, Engineering, Procurement, and Construction (EPC) contracts which in the Construction Law are known as integrated construction contracts. Build Operate Transfer contracts and other models. [5]

With these several types of contracts, it is hoped that they can support the Indonesian government's efforts to accelerate the construction of oil and gas infrastructure. The existence 
of adequate oil and gas supporting infrastructure is one of the factors that attract investment without neglecting legal certainty, a streamlined and efficient licensing bureaucracy, guaranteed political stability and security as well as adequate investment guarantees and protection. [6]

It is unfortunate that until now there are no rules governing contracting procedures or specific contract law rules. So that the definition and implementation of the agreement still refers to the Civil Code (hereinafter referred to as the Civil Code) where the definition of the agreement is contained in Article 1313 of the Civil Code, "an act whereby one or more persons bind themselves to one or more other people." The definition of a construction work contract is contained in Article 1 paragraph (8) of Law Number 2 of 2017 concerning Construction Services (hereinafter referred to as the Construction

Law). A construction work contract is defined as the entire contract document that regulates the legal relationship between service users and service providers in the provision of construction services. Other regulations regarding freedom of contract are written in Article 1 paragraph (1) UNIDROIT, "the parties are free to enter into a contract and to determine its content".[7] What is translated into Indonesian with free translation means that the parties are free to sign the contract and determine the content. However, even though the Civil Code and the UPICC mention the application of freedom of contract, freedom of contract cannot be absolutely free without rules.

The principle of freedom of contract cannot run alone but must be followed by other principles, one of which is the principle of good faith, in which the principle of good faith must always be applied to every agreement made and carried out by the parties. In practice, it is very rare for the parties to enter into an agreement to have an equal position as stated in the UPICC. In such an agreement, the party with a stronger bargaining position tends to determine the contents of the agreement as disclosed in the exploitation de homme par l'homme [8] and those in a weak position will follow, submit and / or obey the party that has a dominant position or more. stronger as a result of the agreement he made.

\section{Research Methods}

The research method used in this research is normative legal research method, which is often called doctrinal research or doctrinal law research. [9] Doctrinal research is defined as research which provides a systematic exposition of the rules governing a particular legal category, analyses the relationship between rules, explains areas of difficulty and estimates of future development. [10] Therefore, it can be said that the type of legal research used in this research is normative, so it can be said that the purpose of the research is a new science and where the scientist must be responsible for each choice of a particular method of interpretation. Because interpretation has a hermeneutic character or interpretation is defined as the process of changing something or a situation of ignorance into understanding. [11]

There are two kinds of approaches used in the research, namely the constitutional approach and also the case approach. In the statutory approach, proof is done by tracing all laws and regulations related to the legal issue that is being handled. Meanwhile, the case approach is an approach that is carried out by tracing several cases that have a connection with the issue at hand or which have permanent legal force, which is analysed using a variety of legal points of view. 


\section{Results and Discussion}

The rapid development of oil and gas construction services in Indonesia needs to be accommodated quickly. The impact on the current oil and gas construction law in Indonesia needs to be reformed, one of which aims to facilitate and clarify the rights and obligations among the parties contained in the contract so that justice can be achieved in implementation.

In this regard, it is important to see that there have been many regulations regarding the implementation of oil and gas construction contracts, however, the freedom to contract that business actors have been dreaming of is still not fully felt. One of the reasons is, the arrangements that knock one another off. As stated by Nonet and Selznick, the goal of justice can be achieved through a system of rules and procedures. As a result, law enforcement in Indonesia still tends to be legal formalistic, and law enforcers use the horse's eye glasses to enforce the law in society. The level of development of the society in which law is enforced affects the pattern of law enforcement, because in modern society it is rational and has a high degree of specialization and differentiation in the organization of law enforcers and is also increasingly complex and highly bureaucratic. [12] Law plays an important role in realizing the welfare of society. This role will only be realized if the substance of the law is truly in favor of the interests of the wider community and in law enforcement that prioritizes the values of justice because the essence and essence of law is justice. [13]

The legal substance which refers to the view of Lawrence M. Friedman, where three subsystems are explained, namely legal substance, legal structure and legal culture. [14] One of the subsystems that have come under the spotlight is legal substance. This is because of how the arrangement of rules and regulations regarding how an institution behaves. [15] This concerns the prevailing laws and regulations which have binding force and serve as guidelines for law enforcement officials. That is, if the legal structure is unable to enforce the law, it will create disobedience to the law. Thus, the legal structure that is not optimal will create a culture of twisting and abusing the law. This is supported by the opinion, according to Harun Nasution, that law enforcement problems can also arise as a result of not or lack of firmness in a provision contained in legislation which opens up the possibility of irregularities by the implementers, so that it will directly or indirectly affect the authority of the implementers. [16]

When the affirmation in this matter is reflected, one of them is from the regulation of Law No. 24 of 2009 concerning the Flag, Language, National Symbol and National Anthem (hereinafter referred to as the Language Law) in Article 31 paragraph (1) of the Language Law which reads: Indonesian must be used in memoranda of understanding or agreements involving State institutions, government agencies of the Republic of Indonesia, Indonesian private institutions or individuals of Indonesian citizenship. Where contradictory conditions occur when the parties want to make amendments to the agreement but in practice, they do not use Indonesian, but the contract uses bilingual (Indonesian and English). Even though it is clearly stated in the contract that the attachments to the contract are parts that are not inseparable from the contract and constitute one unit

This condition, if it is related to the application of the principle of freedom of contract, cannot fully act freely because of the limitations in the Civil Code, namely Article 1320 of the Civil Code j.o. Article 1337 of the Civil Code, which stipulates that parties are not free to make contracts involving clauses prohibited by law or contrary to decency or contrary to public order. This condition has the potential to occur because in implementation there is no mention of any sanctions, even though this rule has an impact on agreements that can be terminated due to conflicts with the rules in the Civil Code. Rigor in this matter is needed and strict derivative rules of the criteria are needed. Of course, this is seen based on Friedman's 
view, by using the perspective of a legal structure, this condition confuses law enforcers to carry out their duties so as to interpret it by using the expansion of interpretation.

As a matter of fact, there is jurisprudence regarding the cancellation of foreign language contracts carried out by the West Jakarta District Court in 2012 through decision Number 451 / PDT.G/ 2012 / PN.JKT.BAR where the disputing parties are PT Bangun Karya Pramalestari and NINE AM Ltd in their decision, the panel of judges stated that the agreement that had been made was null and void because it contradicted the Language Law. Of course, this reinforces the concept

Another lack of affirmation from the regulation of Article 46 of the Construction Law which states that the formation and preparation of integrated construction contracts follows the delivery system, meaning that the contract arrangement mechanism is based on regulations in each institution. The use of the sentence delivery system is considered vulnerable because it does not have the same standards as the employer. One of the impacts is the large number of permit documents required and the potential for overlapping between one agency and another.

Until the issuance of Government Regulation Number 22 of 2020 concerning Implementation Regulations of Law Number 2 of 2017 concerning Construction Services, the regulation and mandate in Article 51 of the Construction Law which will reorganize by Government Regulation has not been realized, this means that there are still empty spaces so that in its application creates a lot of injustice because it does not have the same standards as the employer. One of the impacts is the large number of permit documents required and the potential for overlapping between one agency and another.

For example, in the implementation of the SKK MIGAS Work Procedure Guidelines No.: PTK- 007 / SKKMA0000 / 2017 / S0 (Revision-04) which is a product of SKK Migas which in fact is a state organ (Kementrian ESDM) in its implementation it does not regulate or make reference to standard agreement used in the contract between the KKKS and the contractor. In general, the rules regarding standard agreements that can be referred to in addition to the PK Law are the Civil Code, which only regulates lawful causes whose meaning and interpretation are very broad, causing uncertainty and causing many difficulties in practice because the regulator itself does not act firmly on the regulations it makes.

The perspective that may be used on this condition is an inverse perspective which when referring to Article 4.6 of the UPICC is known as interpretation using the contra preferentum. Because if the contract is always interpreted from the contractor, the contractor will always appear to be disobeying the principles of the agreement, so the contract must be interpreted in reverse, namely from the side of the work executor. This was further strengthened by the provisions in UPICC Article 2.1.15 paragraph 2 which reads However, a party who negotiates or breaks off negotiations in bad faith is liable for the losses caused to the other party. (However, the party negotiating or terminating the negotiations in bad faith is responsible for the harm caused to the other party.)

In a standard private agreement, especially the construction agreement in the oil and gas sector, it often causes the position of the parties to be unbalanced. The weak party is usually not in a state of freedom to determine what he wants in the agreement because the employer dominates in determining matters that are directly or indirectly related to the performance of the work. This condition causes the party in a dominant position to take advantage of the opportunity to determine certain clauses to accommodate or dominate their interests. It can be ascertained that the agreement will contain clauses that are favorable to the employer or remove certain obligations that should be borne by the employer plus certain obligations that are burdensome for the implementer of the work. 
This condition is exacerbated due to the existence of an exonation clause, where the prohibition on the use of this clause is regulated in Article 18 paragraph (1) letter a of the Company Law which explains the exonation clause in the standard agreement, which is an effort to transfer responsibility from the business actor to the executor which should not have been allowed by Constitution. However, in fact there are still exonation clauses found in the standard agreements made by business actors.

According to Gustav Radbruch, justice and legal certainty when associated with contract execution are permanent parts of law. That justice and legal certainty must be considered, legal certainty must be maintained for the sake of security and positive law must always be obeyed for the orderliness of a country. Based on the theory of legal certainty, what you want to achieve is the value of justice and happiness. [17] The desired goal of justice is the execution of a contract in accordance with the rules and regulations that apply in the contract

\section{Conclusion}

Basically, the arrangements that guarantee the freedom to contract in an oil and gas construction contract are certainly sufficient. However, in substance there are still several provisions that require improvement. Among them, the provisions in the Civil Code require renewal, including redefining the principles of the validity of the agreement.

The disruptions faced by contractors in the implementation stage include delays in billing, down payment arrangements, use of contract money, differences in tender documents, independent contractors, amendment processes, unilateral terminations, work freezing, settlement mechanisms that will be used in the event of a dispute between the parties. which then leads to the imposition of sanctions for defeat in disputes with KKKS or SKK Migas.

In accordance with the results of the study of the normative and empirical juridical aspects, it is deemed necessary to carry out regulatory reforms with the aim of primarily preventing and minimizing the occurrence of injustice. In addition, to increase legal certainty in contract norms as well as efficiency in contract execution. In this case, the solution offered is to regulate the contract exit mechanism. This is to be able to provide certainty on the timing of contract issuance and the process of clarifying standard contract norms, along with norms to anticipate differences between contracts and tender documents. In addition, it is necessary to regulate the provisional sum to be able to provide convenience and flexibility when there is a change in work implementation. In line with that, the amendments that are usually carried out with addendums can be replaced by the SPK system, which is signed based on the financial authority level. This step can cut into the contract administration and implementation process.

\section{Acknowledgments}

The author wishes to thank the Head of Christian University of Indonesia and Head of Faculty of Law for providing a facility to join International Conference on Law and Human Rights ICLHR 2021 UKI 


\section{References}

[1] Achmad Ali, Menguak Tabir Hukum (Suatu Kajian Filosofis dan Sosiologis), Jakarta: Penerbit Toko Gunung Agung, 2002.

[2] Bambang Waluyo, Penyelesaian Perkara Pidana: Penerapan Keadilan Restoratif dan Trasnformatif, Jakarta: Sinar Grafika, 2020.

[3] E. Sumaryono, Hermeneutik Sebuah Metode Filsafat, Yogjakarta: Penerbit Kanisius, 1993,

[4] I.B.R. Supancana, Aspek-Aspek Hukum Kontrak Dalam Pembangunan dan Pengoperasian Insfrastruktur dengan Pola BOT (Build, Operate and Transfer), Jakarta: Badan Pembinaan Hukum Nasional Departemen Hukum dan Hak Asasi Manusia, 2008.

[5] Lawrence M. Friedman; The Legal System; A Social Scince Prespective, New York: Russel Sage Foundation, 1975.

[6] Munir Fuady, Kontrak Pemborongan Mega Proyek, PT Citra Aditya Bakti, 1998.

[7] Yudi Latif, Negara Paripurna, Historisitas, Rasionalitas, dan Aktualitas Pancasila, Jakarta: Gramedia Pustaka Utama, 2011.

[8] Valerine J.L.K, Mode Penelitian Hukum (Bagian 1) Edisi Revisi, Jakarta: Program Pasca Sarjana Universitas Indonesia, 2015,

[9] M. Yasin Al Arif, Penegakan Hukum dalam Perspektif Hukum Progresif, Undang: Jurnal Hukum, ISSN 2598-7933(Online); 2598-7941 (Cetak), Vol. 2 No.1, 2019.

[10] Sanyoto, "Penegakakan Hukum di Indonesia", Jurnal Dinamika Hukum, Vol. 8, No.3 Tanggal 3 September 2008.

[11] Winda Roselina Effendi, Jurnal Trias Politika, Trias Politika, Vol 1 No.1 April 2017, Konsep Wellfare State di Indonesia.

[12] Yohanes Suhardin, "Peranan Hukum dalam Mewujudkan Kesejahteraan Masyarakat", Jurnal Hukum Pro Justitia Volume 25, No. 3, Juli 2007,

[13] Rencana strategis 2015-2019 Kementrian Energi dan Sumber Daya Mineral Direktorat Jendral Minyak dan Gas Bumi. Hal. 30. Diakses via https://www.migas.esdm.go.id/uploads/uploads/renstra-migas-2015-2019.pdf. Pada tanggal 3 Februari 2019. Pukul 11.48 WIB

[14] Diakses via https://www.unidroit.org/instruments/commercial-contracts/unidroit-principles2010/414-chapter-1-general-provisions/863-article-1-1-freedom-of-contract. Pada tanggal 23 Maret 2019. Pukul 22.15 WIB. 